\title{
Ketahanan Penyakit Antraknosa terhadap Cabai Lokal dan Cabai Introduksi
}

\section{Resistance to Anthracnose on Local and Introduction Chilies}

\author{
Abdul Hakim ${ }^{1}$, Muhamad Syukur ${ }^{1 *}$, Widodo $^{2}$ \\ ${ }^{1}$ Departemen Agronomi dan Hortikultura, Fakultas Pertanian, Institut Pertanian Bogor \\ (Bogor Agricultural University), Jl. Meranti, Kampus IPB Dramaga, Bogor 16680, Indonesia \\ Telp \& Faks. 62-251-8629353 e-mail agronipb@indo.net.id \\ ${ }^{2}$ Departeman Proteksi Tanaman, Fakultas Pertanian IPB \\ J1 Kamper, Kampus IPB Dramaga Bogor 16680, Indonesia \\ *) penulis untuk korespondensi : muhsyukur@ipb.ac.id \\ Disetujui /Published online
}

\begin{abstract}
Diseases that cause low productivity of chili in Indonesia is anthracnose. This study aimed to obtain genotypes of chili plants that are resistant to anthracnose disease caused by Colletotrichum acutatum. The research was conducted in field and laboratory, using a randomized complete design group, one factor and two replications. Isolate of Colletotrichum acutatum used were BGR 027, PYK 04 and BKT 05. The results showed that the genotype IPB C15 has the best resistance against three isolates of Colletotrichum acutatum. This genotype is one source for chili resistance to anthracnose disease and the potential to be a donor for this character. Introduction genotypes is more dominant than local genotypes for resistance properties. the exploration needs to be done to get local genotypes anthracnose resistant.
\end{abstract}

Key words: anthracnose, chili, Colletotrichum acutatum, resistance

\section{ABSTRAK}

Penyakit yang menyebabkan rendahnya produktivitas cabai di Indonesia adalah antraknosa. Penelitian ini bertujuan untuk mendapatkan genotipe tanaman cabai yang tahan terhadap penyakit antraknosa yang disebabkan oleh Colletotrichum acutatum. Penelitian ini dilakukan di lapangan dan laboratorium, menggunakan Rancangan Kelompok Lengkap Teracak, satu faktor dan dua ulangan. Isolat Colletotrichum acutatum yang digunakan adalah BGR 027, PYK 04 dan BKT 05. Hasil penelitian menunjukkan bahwa genotipe IPB C15 memiliki ketahanan paling baik terhadap tiga isolat Colletotrichum acutatum. Genotipe ini merupakan salah satu sumber untuk sifat ketahanan cabai terhadap penyakit antraknosa. Genotipe introduksi lebih mendominasi untuk sifat ketahanan dan keragaan daya hasil daripada genotipe lokal. Dengan demikian perlu dilakukan eksplorasi untuk mendapatkan genotipe lokal yang tahan antraknosa.

Kata kunci: antraknosa, cabai, Colletotrichum acutatum, ketahanan

\section{PENDAHULUAN}

Produktivitas tanaman cabai di Indonesia pada tahun 2008 mencapai 6.37 ton ha $^{-1}$ (Badan Pusat Stasistik, 2009). Angka tersebut relatif rendah jika dibandingkan dengan potensi produktivitasnya yang mencapai 12 ton ha ${ }^{-1}$ (Purwati et al., 2000). Rendahnya produksi cabai besar di Indonesia disebabkan oleh beberapa hal diantaranya adalah teknik budidaya yang belum optimal, minimnya benih bermutu, tingginya serangan hama penyakit serta faktor lingkungan yang kurang menguntungkan. Salah satu faktor dominan yang menyebabkan rendahnya produktivitas cabai di Indonesia adalah adanya gangguan hama dan penyakit (Semangun, 2000; Nawangsih et al., 2003).

Penyakit yang paling dominan menyebabkan rendahnya produksi cabai di Indonesia adalah antraknosa (Suryaningsih et al., 1996). Penyakit antraknosa ini disebabkan oleh cendawan Colletotrichum sp yang distimulir oleh kondisi 
lembab dan suhu relatif tinggi (AVRDC, 1988). Penyakit antraknosa pada tanaman cabai disebabkan oleh tiga species cendawan Colletotrichum yaitu Colletotrichum acutatum, Colletotrichum gloeosporioides, dan Colletotrichum capsici (AVRDC, 2003).

Colletotrichum gloeosporioides merupakan spesies yang paling luas serangannya pada tanaman Solanaceae terutama pada tanaman cabai namun akhir-akhir ini spesies yang utama menyerang cabai adalah spesies Colletotrichum acutatum (Park, 2005).

Berdasarkan laporan Badan Penelitian Hortikultura Lembang dalam Hariati (2007), kehilangan hasil pada pertanaman cabai akibat serangan antraknosa dapat mencapai $50-100 \%$ pada musim hujan. Sementara berdasarkan Widodo (2007), kehilangan hasil produktivitas cabai sekitar $10-80 \%$ di musim hujan dan $2-35 \%$ di musim kemarau. Menurut Setiadi (2008), penyakit antraknosa menyerang buah, baik buah muda atau buah yang telah matang akan tampak bercakbercak yang semakin lama akan semakin melebar, selanjutnya buah akan mengerut dan mengering dengan warna kehitaman.

Pemuliaan tanaman bertujuan untuk mengembangkan varietas unggul, baik untuk tanaman hortikultura maupun tanaman pangan salah satunya melalui perbaikan adaptasi tanaman terhadap cekaman biotik dan abiotik. Kegiatan pemuliaan tanaman untuk perbaikan daya adaptasi terhadap cekaman biotik salah satunya adalah pemuliaan cabai resisten penyakit antraknosa. Peningkatan resistensi tanaman terhadap penyakit antraknosa ini bertujuan untuk memperoleh tanaman cabai yang tahan terhadap penyakit antraknosa sehingga dapat memperbaiki daya hasil. Penelitian ini merupakan tahapan perakitan varietas tanaman cabai tahan antraknosa dalam rangka perbaikan produktivitas, kualitas dan adaptasi terhadap cekaman biotik.

Penelitian ini bertujuan untuk mendapatkan genotipe tanaman cabai yang tahan terhadap penyakit antraknosa.

\section{BAHAN DAN METODE}

Penelitian ini dilaksanakan pada bulan April sampai dengan September 2009. Bertempat di Kebun Percobaan Leuwikopo dengan ketinggian \pm 190 m dpl dan Laboratorium Bagian Genetika dan Pemuliaan Tanaman Departemen Agronomi dan Hortikultura.

Bahan yang digunakan pada penelitian ini adalah 17 genotipe cabai yaitu IPB C2, IPB C4a,
IPB C5a, IPB C10, IPB C14, IPB C15, IPB C19, IPB C20, IPB C105, IPB C110, IPB C126, IPB C128, IPB C129, IPB C130 IPB C131, IPB C132, dan IPB C133. Isolat Colletotrichum acutatum yang digunakan adalah BGR 027, PYK 04 dan BKT 05.

Penelitian ini dilakukan di lapangan dan laboratorium menggunakan rancangan lingkungan RKLT dengan faktor tunggal. Percobaan di lapangan yaitu 17 genotipe cabai dan diulang 2 kali. Sehingga terdapat 34 satuan percobaan. Percobaan yang dilakukan di laboratorium yaitu 17 genotipe tanaman cabai dan diulang 2 kali. Sehingga terdapat 34 satuan percobaan. Jumlah buah yang diinokulasi untuk masing-masing genotipe 20 buah cabai yang belum matang dan mencapai ukuran maksimum.

Media persemaian terlebih dahulu dioven pada suhu $100^{\circ} \mathrm{C}$ selama 3 jam. Media yang telah dioven didinginkan, kemudian ditempatkan ke dalam tray, setelah itu benih cabai ditanam pada tray yang telah diisi media tanam. Selama masa pembibitan, pemeliharaan yang dilakukan berupa pemupukan dan pengendalian hama dan penyakit tanaman. Pupuk yang digunakan adalah NPK Mutiara konsentrasi $10 \mathrm{~g}$ L-1 dan pupuk daun Gandasil 1-3 g L-1. Tanaman cabai yang telah memiliki daun $\pm 4-5$ helai atau selama 6 minggu kemudian ditanam di lapangan. Lahan disiapkan 2 minggu sebelum tanam. Pupuk dasar berupa pupuk kandang dengan dosis 20 ton $\mathrm{ha}^{-1}$. Tanah diolah sehingga bercampur dengan pupuk kandang, kemudian dibuat bedengan dengan ukuran lebar 1 $\mathrm{m}$, panjang $5 \mathrm{~m}$, jarak antar bedeng $50 \mathrm{~cm}$, tinggi bedeng $30 \mathrm{~cm}$. Bedeng ditutup dengan mulsa plastik hitam perak setelah ditaburi dengan pupuk urea, SP-18 dan $\mathrm{KCl}$, kemudian dibuat lubang tanam $50 \mathrm{~cm} \times 50 \mathrm{~cm}$. Bibit ditanam pada lubang tanam yang telah diberi karbofuran, kemudian diberi ajir bambu untuk mencegah tanaman rebah. Kegiatan pemeliharaan tanaman meliputi pemupukan, penyiraman, pewiwilan, penyiangan serta pengendalian hama dan penyakit. Pemupukan menggunakan pupuk NPK dengan konsentrasi 10 gL-1 dilakukan seminggu sekali. Pupuk diaplikasikan dalam bentuk cair dengan dosis 250 $\mathrm{ml}$ per tanaman. Pewiwilan yaitu membuang tunastunas air yang tumbuh. Penyiangan gulma dilakukan seminggu sekali. Pengendalian hama penyakit dilakukan apabila terjadi serangan hama.

Pembuatan isolat dilakukan dengan menyiapkan potongan dari konidia (biakan murni) kemudian dibiakkan pada media Potato Dextrose Agarose (PDA) dalam cawan petri setelah itu disimpan pada suhu $28^{\circ} \mathrm{C}$ dengan intensitas cahaya 
12 jam per hari selama 5-7 hari. Konidia dipanen dengan memasukkan air sebanyak $20 \mathrm{ml}$ ke dalam cawan kemudian permukaan isolat digosok perlahan dengan menggunakan gelas L. Suspensi konidia tersebut kemudian disaring dengan menggunakan kertas saring. Untuk menentukan kepadatan inokulum yang diperlukan $5 \times 10^{5}$ konidia m L-1 (AVRDC 2003), konidia cendawan dihitung dengan bantuan mikroskop dan haemocytometer. Buah cabai yang akan diinokulasi adalah buah cabai hijau tua yang belum matang. Cabai tersebut dicuci terlebih dahulu dan dikeringkan. Metode inokulasi yang digunakan adalah metode suntik. Inokulasi dilakukan dengan menyuntikkan inokulum cendawan isolat Colletotrichum acutatum BGR 027, isolat PYK 04 dan isolat BKT 05, berupa suspensi konidia, ke dalam buah cabai. Inokulasi dilakukan dengan cara menyuntikkan $2 \mu 1$ inokulum sebanyak 2 suntikan pada daerah yang berbeda (untuk buah yang berukuran $<4 \mathrm{~cm}$ hanya 1 suntikan per buah). Buah cabai yang telah diinokulasi disimpan di atas anyaman kawat di dalam bak plastik yang sebelumnya sudah disterilisasi dan dialasi dengan tissue basah kemudian dibungkus dengan plastik untuk menjaga kelembaban dalam bak plastik.

Kejadian penyakit (KP), dihitung berdasarkan persentase buah yang terkena serangan. Identifikasi buah yang terserang dengan melihat adanya bercak nekrosis pada hari ke-5 setelah inokulasi, dengan persamaan:

$$
K P=\frac{n}{N} \times 100 \%
$$

Keterangan :

$\begin{array}{ll}\mathrm{KP} & =\text { kejadian penyakit } \\ \mathrm{n} & =\text { buah terserang } \\ \mathrm{N} & =\text { jumlah buah total }\end{array}$

Buah dianggap terserang jika diameter nekrosis $\geq 4 \mathrm{~mm}$. Persentase yang dihasilkan setiap genotipe yang diuji kemudian ditentukan kelas ketahanannya berdasarkan Yoon (2003) yang dimodifikasi Syukur (2007) seperti pada Tabel 1.

Tabel 1. Kriteria ketahanan antraknosa

\begin{tabular}{ccc}
\hline Persentase & Skor & $\begin{array}{c}\text { Kriteria } \\
\text { Ketahanan }\end{array}$ \\
\hline $0 \leq \mathrm{KP} \leq 10$ & 1 & Sangat tahan \\
$10<\mathrm{KP} \leq 20$ & 2 & Tahan \\
$20<\mathrm{KP} \leq 40$ & 3 & Moderat \\
$40<\mathrm{KP} \leq 70$ & 4 & Rentan \\
$\mathrm{KP}>70$ & 5 & Sangat rentan \\
\hline
\end{tabular}

Diameter Nekrosis (DN) ditentukan dengan cara mengukur diameter nekrosis pada buah yang terserang setelah diinokulasi pada hari ke-7.

Data kuantitatif dianalisis dengan menggunakan uji analisis ragam (ANOVA) pada taraf $5 \%$. Apabila hasil pengujian menunjukkan pengaruh yang nyata, dilakukan uji lanjut Duncan's Multiple Range Test (DMRT) pada taraf 5\%.

\section{HASIL DAN PEMBAHASAN}

\section{Ketahanan terhadap Penyakit Antraknosa}

Karakter yang diamati pada pengujian ketahanan terhadap penyakit antraknosa ini meliputi kejadian penyakit (KP) dan diameter nekrosis.

\section{Kejadian Penyakit (KP)}

Genotipe yang diinokulasi dengan isolat $C$. acutatum BGR 027 (Tabel 2) menunjukkan kejadian penyakit berkisar antara $45 \%$ sampai $100 \%$. Terdapat satu genotipe yang termasuk dalam kriteria rentan yaitu genotipe IPB C15, sementara genotipe yang lain termasuk dalam kriteria sangat rentan. Genotipe yang diinokulasi dengan isolat $C$. acutatum PYK 04 menunjukkan kejadian penyakit berkisar antara $2.5 \%$ (IPB C15) sampai $67.5 \%$ (IPB C19). Terdapat satu genotipe yang termasuk kriteria sangat tahan yaitu IPB C15. Dua genotipe termasuk dalam kriteria tahan yaitu IPB C20 dan IPB C128.

Tabel 2. Kriteria ketahanan cabai terhadap penyakit antraknosa

\begin{tabular}{|c|c|c|c|c|c|c|}
\hline \multirow[b]{2}{*}{ Genotipe } & \multicolumn{6}{|c|}{ Kejadian Penyakit (\%) } \\
\hline & $\begin{array}{c}\text { BGR } \\
027\end{array}$ & Kriteria & $\begin{array}{c}\text { PYK } \\
04\end{array}$ & Kriteria & $\begin{array}{c}\text { BKT } \\
05\end{array}$ & Kriteria \\
\hline IPB C2 & 100 & SR & 50 & $\mathrm{R}$ & 37.5 & M \\
\hline IPB C4a & 100 & SR & 22.5 & M & 70 & $\mathrm{R}$ \\
\hline IPB C5a & 100 & SR & 40 & M & 72.5 & $\mathrm{R}$ \\
\hline IPB C10 & 100 & SR & 32.5 & M & 75 & SR \\
\hline IPB C14 & 100 & SR & 62,5 & $\mathrm{R}$ & 65 & $\mathrm{R}$ \\
\hline IPB C15 & 45 & $\mathbf{R}$ & 2.5 & ST & 0 & ST \\
\hline IPB C19 & 100 & SR & 67.5 & $\mathrm{R}$ & 80 & SR \\
\hline IPB C20 & 100 & SR & 17.5 & $\mathrm{~T}$ & 52.5 & $\mathrm{R}$ \\
\hline IPB C105 & 97.5 & SR & 37.5 & M & 65 & $\mathrm{R}$ \\
\hline IPB C110 & 100 & SR & 62.5 & $\mathrm{R}$ & 77.5 & SR \\
\hline IPB C126 & 100 & SR & 22.5 & M & 37.5 & M \\
\hline IPB C128 & 100 & SR & 17.5 & $\mathrm{~T}$ & 57.5 & $\mathrm{R}$ \\
\hline IPB C129 & 92.5 & SR & 57.5 & $\mathrm{R}$ & 57.5 & $\mathrm{R}$ \\
\hline IPB C130 & 100 & SR & 42.5 & $\mathrm{R}$ & 40 & M \\
\hline IPB C131 & 97.5 & SR & 22.5 & M & 40 & M \\
\hline IPB C132 & 100 & SR & 37.5 & M & 65 & $\mathrm{R}$ \\
\hline IPB C133 & 100 & SR & 37.5 & M & 52.5 & $\mathrm{R}$ \\
\hline
\end{tabular}


Delapan genotipe termasuk dalam kriteria moderat yaitu IPB C4a, IPB C5a, IPB C10, IPB C105, IPB C126, IPB C131, IPB C132, dan IPB C133. Enam genotipe termasuk dalam kriteria rentan yaitu IPB C2, IPB C14, IPB C19, IPB C110, IPB C129, dan IPB C130.

Genotipe yang diinokulasi dengan isolat $C$. acutatum BKT 05 menunjukkan kejadian penyakit berkisar antara 0\% (IPB C15) sampai 77.5\% (IPB C110). Terdapat satu genotipe yang termasuk kriteria sangat tahan yaitu IPB C15. Empat genotipe termasuk dalam kriteria moderat yaitu IPB C2, IPB C126, IPB C131, dan IPB C132. Sembilan genotipe termasuk dalam kriteria rentan yaitu IPB C4a, IPB C5a, IPB C14, IPB C20, IPB C105, IPB C128, IPB C129, IPB C132, dan IPB C133. Tiga genotipe termasuk dalam kriteria sangat rentan yaitu IPB C10, IPB C19, dan IPB C110. Kriteria Ketahanan cabai terhadap masingmasing isolat $C$. acutatum sangat beragam. Kriteria ketahanan cabai terhadap isolat $C$. acutatum BGR 027 hanya dua yaitu sangat rentan (SR) dengan rentan (R), sementara terhadap isolat $C$. acutatum PYK 04 terdapat empat yaitu sangat tahan (ST), tahan $(\mathrm{T})$, moderat $(\mathrm{M})$ dan rentan $(\mathrm{R})$. Kriteria ketahanan cabai terhadap isolat $C$. acutatum BKT 05 terdapat empat yaitu sangat tahan (ST), moderat (M), rentan (R), dan sangat rentan (SR). Perbedaan kriteria ketahanan ini disebabkan oleh faktor patogen, inang dan lingkungan. Pengujian untuk ketahanan penyakit antraknosa, faktor lingkungan dan inang telah diseragamkan, sehingga perbedaan kriteria ketahanan disebabkan oleh faktor genetik dari isolat yang digunakan.

Berdasarkan Tabel 2, isolat $C$. acutatum BGR 027 merupakan isolat paling virulen dibandingkan dengan kedua isolat yang lain. Hal ini terlihat dari kriteria ketahanan hanya terdapat dua macam yaitu rentan (R) dan sangat rentan (SR). Genotipe cabai IPB C15 yang pada isolat PYK 04 dan BKT 05 termasuk dalam kriteria sangat tahan (ST) sedangkan pada isolat $C$. acutatum BGR 027 termasuk rentan (R). Hal ini menunjukkan bahwa tingkat virulensi isolat $C$. acutatum BGR 027 sangat tinggi dibandingkan dengan kedua isolat yang lain. Virulensi isolat $C$. acutatum ini berbeda diduga disebabkan karena tempat pengujian yang dilakukan di Bogor. Kedua isolat yang lain merupakan isolat yang berasal dari luar Bogor. Isolat $C$. acutatum BKT 05 berasal dari Bukittinggi dan isolat $C$. acutatum PYK 04 berasal dari Payakumbuh. Perbedaan yang paling mencolok adalah isolat $C$. acutatum BKT 05 merupakan $C$. acutatum yang berasal dari dataran tinggi sedangkan isolat $C$. acutatum BGR 07 merupakan C. acutatum yang berasal dari dataran rendah.

Proses pengujian antraknosa ini dilakukan di Bogor yang merupakan daerah dataran rendah. Virulensi isolat $C$. acutatum BKT 05 diduga menurun karena perbedaan lingkungan. Pembentukan penyakit sangat ditentukan oleh tiga komponen yang harus selalu berinteraksi. Komponen penyakit tumbuhan yaitu patogen, inang dan lingkungan abiotik dan biotik. Komponen-komponen tersebut dapat berubah-ubah sifatnya, sehingga bila satu komponen saja berubah maka akan mempengaruhi tingkat serangan penyakit pada inangnya (Sinaga, 2000). Genotipe IPB C15 memiliki ketahanan terhadap penyakit yang lebih baik terhadap ketiga isolat Colletotrichum acutatum (Tabel 2). Genotipe IPB C15 merupakan introduksi dari AVRDC dengan kode genotipe 0209-4. Genotipe IPB C15 diduga memiliki ketahanan fungsional (biokimiawi) terhadap penyakit antraknosa karena metode yang digunakan adalah dengan menyuntikkan inokulum langsung ke dalam buah sehingga tidak menampilkan ketahanan struktural pada buah cabai.

\section{Diameter Nekrosis}

Berdasarkan Tabel 3 menunjukkan bahwa dari tiga isolat yang digunakan hanya isolat $C$. acutatum BGR 027 memberikan perbedaan sangat nyata pada genotipe yang diuji sedangkan untuk isolat PYK 04 dan BKT 05 tidak menunjukkan perbedaan yang nyata.

Tabel 3. Rekapitulasi sidik ragam diameter nekrosis

\begin{tabular}{lll}
\hline Isolat & F hitung & KK $(\%)$ \\
\hline BGR027 & $4.38^{* *}$ & 13.22 \\
PYK04 & $2.06^{\text {tn }}$ & 30.43 \\
BKT05 & $1.87^{\text {tn }}$ & 16.56 \\
\hline
\end{tabular}

Keterangan : ** = berbeda nyata pada taraf $1 \%$

$$
\mathrm{tn}=\text { tidak nyata }
$$

Diameter nekrosis ini menunjukkan tingkat keparahan rusaknya jaringan kulit permukaan pada buah cabai yang disebabkan oleh Colletotrichum acutatum. Semakin lebar jaringan kulit tanaman yang rusak menunjukkan bahwa isolat Colletotricum acutatum yang digunakan diduga memiliki tingkat virulensi yang tinggi.

Isolat Colletotrichum acutatum BGR 027 diduga merupakan isolat yang memiliki tingkat virulensi yang tinggi, hal ini dapat dilihat dari nilai 
kejadian penyakit diatas $90 \%$, hanya genotipe IPB C15 yang memiliki nilai kejadian penyakit $45 \%$. Hasil uji lanjut untuk diameter nekrosis yang disebabkan oleh isolat $C$. acutatum BGR 027 menunjukkan tiap genotipe berbeda (Tabel 4). Genotipe yang memiliki nilai tengah paling kecil adalah genotipe IPB C15. Hal ini menunjukkan genotipe IPB C15 memiliki ketahanan terhadap serangan antraknosa yang lebih baik dibandingkan dengan genotipe yang lain.

Tabel 4. Nilai tengah diameter nekrosis isolat C. acutatum BGR 027

\begin{tabular}{cc}
\hline Genotipe & $\begin{array}{c}\text { Diameter Nekrosis } \\
(\mathrm{mm})\end{array}$ \\
\hline IPB C5a & $15.96^{\mathrm{bc}}$ \\
IPB C4a & $15.15^{\mathrm{bc}}$ \\
IPB C5a & $15.28^{\mathrm{bc}}$ \\
IPB C10 & $14.16^{\mathrm{bc}}$ \\
IPB C14 & $19.17^{\mathrm{ab}}$ \\
IPB C15 & $\mathbf{8 . 2 5}^{\mathrm{bc}}$ \\
IPB C19 & $21.69^{\mathrm{a}}$ \\
IPB C20 & $11.19^{\mathrm{bc}}$ \\
IPB C105 & $18.48^{\mathrm{ab}}$ \\
IPB C110 & $16.90^{\mathrm{ab}}$ \\
IPB C126 & $16.72^{\mathrm{ab}}$ \\
IPB C128 & $18.69^{\mathrm{ab}}$ \\
IPB C129 & $15.74^{\mathrm{bc}}$ \\
IPB C130 & $14.59^{\mathrm{bc}}$ \\
IPB C131 & $15.80^{\mathrm{bc}}$ \\
IPB C132 & $17.51^{\mathrm{ab}}$ \\
IPB C133 & $16.97^{\mathrm{ab}}$ \\
\hline Keterangan: nilai tengah yang diikuti oleh huruf yang \\
sama pada kolom yang sama tidak berbeda \\
nyata berdasarkan DMRT pada taraf 5\%
\end{tabular}

\section{KESIMPULAN}

Genotipe IPB C15 merupakan cabai yang memiliki ketahanan paling baik terhadap tiga isolat Colletotrichum acutatum. Genotipe ini merupakan salah satu sumber untuk sifat ketahanan cabai terhadap penyakit antraknosa dan berpotensi untuk dijadikan tetua donor untuk sifat tersebut. Genotipe introduksi lebih mendominasi untuk sifat ketahanan daripada genotipe lokal. Dengan demikian perlu dilakukan eksplorasi untuk mendapatkan genotipe lokal yang tahan antraknosa..

\section{UCAPAN TERIMA KASIH}

Terima kasih disampaikan kepada Tim Hibah KKP3T Kementan 2009 a.n Muhamad Syukur

\section{DAFTAR PUSTAKA}

AVRDC. 1988. Growth Characters and Inoculation Methods of Antrachnose Pathogens. p : 6770. AVRDC Progress Report 1988. Taiwan.

AVRDC. 2003. Evaluation of Phenotypic and Moleculer Criteria for the Identification for Colletotrichum spesies Causing Pepper Antrachnose in Taiwan, p. 58-59. In AVRDC Report 2003. Taiwan.

Badan Pusat Statistik .2009. Luas Panen, Produksi dan Produktivitas Cabai 2008. http://www.bps.go.id/tab_sub/view.php?tabe $\underline{\mathrm{l}=1 \& \text { daftar}=1 \& \text { id_subyek }=55 \& \text { notab }=14}$ [20 Desember 2009].

Hariati, N. 2007. Analisis Keanekaragaman 23 Genotipe Cabai (Capsicum sp.) Berdasarkan Penampakan Fenotipik serta Ketahanannya Terhadap Penyakit Antraknosa (Colletotrichum sp). Skripsi. Departemen Agronomi dan Hortikultura. Fakultas Pertanian. IPB. 53 hal.

Nawangsih, A.A., P. Imdad dan A. Wahyudi. 2003. Cabai Hot Beauty. Penebar Swadaya. Jakarta.128 Hal.

Park. 2005. Differential Interaction Between Pepper Genotypes and Colletotrichum Isolates Causing Anthracnose. Thesis. Soul Nath.Univ. Seoul, Korea. 48 p

Purwati, E., Jaya B., dan Duriat A.S. 2000. Penampilan beberapa varietas cabai dan uji resistensi terhadap penyakit virus kerupuk J.Hort 10 (2) : 88-94

Semangun, H. 2000. Penyakit-Penyakit Tanaman Hortikultura Di Indonesia. $4^{\text {th }}$. Gadjah Mada University Press. Yogyakarta. 850 hal.

Setiadi. 2008. Bertanam Cabai Cetakan XXV. Penebar Swadaya. Jakarta. 183 hal.

Sinaga, M.S. 2000. Dasar-Dasar Ilmu Penyakit Tanaman. Diktat kuliah. Jurusan Hama dan Penyakit Tumbuhan. Institut Pertanian Bogor. 125 hal.

Suryaningsih, E., R. Sutarya dan A.S Duriat. 1996. Penyakit Tanaman Cabai Merah dan Pengendaliannya. Hal 64-84. Dalam A.S. Duriat, A. Widjada, W. Hadisoeganda, T.A. Soetriarso dan L. Purbaningrum (eds). Teknologi Produksi Cabai Merah. Balitsa. Lembang. 
Syukur, M, S. Sujiprihati, J.Koswara, dan Widodo. 2007. Pewarisan ketahanan cabai (Capsicum annuum L) terhadap antraknosa yang disebabkan oleh Colletotrichum acutatum. Bul. Agron. 35(2):112-117.

Widodo. 2007. Status of Chili Antrachnose in Indonesia. p-27. In First International Symposium and Chili Anthracnose. National Horticultural Research Institute, Rural Development of Administration. Republic of Korea. 67

Yoon, J.B. 2005. Identification of Genetic Resources, Intrespesific Hybridization,and Inheritance Analysis for Breeding Pepper (Capsicum annuum) Resistant to Antrachnose [PhD Thesis]. Seoul Univ, Seoul.137 hal 